УДК 35.08:316.47](477)

DOI: 10.34132/pard2020.10.05

\title{
ЛІДЕРСЬКІ ЯКОСТІ НА ДЕРЖАВНІЙ СЛУЖБІ: ПРОБЛЕМНІ ПИТАННЯ
}

Смельянов B.M., д-р наук з держ. упр., професор, Інститут державного управління, Чорноморський національний університет ім. Петра Могили, м. Миколаїв, Україна.

Штирьов О.M., канд., наук з держ. упр., доцент, Інститут державного управління, Чорноморський національний університет ім. Петра Могили, м. Миколаїв, Україна.

Bepбa C.M., ст. викладач, Інститут державного управління, Чорноморський національний університет ім. Петра Могили, м. Миколаїв, Україна.

Ярошенко Л.С., магістр публічного управління, Інститут державного управління, Чорноморський національний університет ім. Петра Могили, м. Миколаїв, Україна.

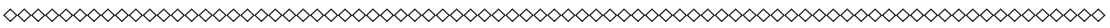

У статті розглядаються питання ефективності управління в умовах постійних перетворень в країні, коли змінюеться роль дерэсави, змінюються державно-управлінські відносини, щзо потребують вдосконалення підходів до становлення потужного кадрового потенціалу з елементами лідерства в державному управлінні.

Проведено аналіз лідерських якостей державних службовиів та посадових осіб місиевого самоврядування. Проведені дослідження, які конкретизували перелік лідерських якостей посадових осіб в органах державної влади. 3'ясовано, щзо лідерство можна визначити як один з процесів організації управління для досягнення найкращого результату в управлінській діяльності.

Встановлено, щуо у більшості керівників немає вроджених задатків до лідерства. Тому необхідно розвивати иі якості через 
спещіальну підготовку, якщзо керівник усвідомлює відповідальність за свій колектив, за доручену справу та відповідальність перед суспільством.

Існує необхідність відбору з числа державних службовичів на керівні посади людей здатних до лідерства, чи в силу вроджених якостей, чи набутих в прочесі тривалої роботи у владних інституиіях. Це потрібно для розвиткупрофесіоналізаціїдержавної служби в Україні. Але, на жаль, цьього майже не відбувається. С кожним роком ми втрачаємо компетентних професіоналів, здатних вивести країну із економічної, сочіальної, політичної кризи.

Ключові слова: лідерство, керівник-лідер, професіоналізація, компетентність, відбір посадовиів.

\section{Постановка проблеми у загальному вигляді. Якість} державного управління завжди залежала, залежить і буде залежати від професіональної компетентності державних службовців та посадових осіб місцевого самоврядування. На теперішній час науковці багато уваги приділяють особливостям взаємодії «керівник-співробітники», особливо проявам такого феномену як лідерство. Ефективність роботи будь-якої державної установи, особливо органів державної влади і місцевого самоврядування залежить від результативності, мотивації співробітників, а як їх спонукати до отримання найкращого результату - найактуальніші питання, які постають перед керівниками державних установ та співробітниками що працюють у цих установах.

Досвід роботи в органах державної влади і виборчих органах дає можливість стверджувати, що як такого лідерства в повному розумінні трактування цього феномену в державному управлінні не існує.

Які перешкоди існують для розвитку лідерства на державній службі і в органах місцевого самоврядування:

- перш за все радянська модель управління, за якої кожний державний службовець $є$ виконавцем від якого залежить тільки своєчасне виконання своїх службових обов'язків (доручили-зробив);

- постійна зміна діючого законодавства. Приходи до 
влади нових Президентів докорінно змінюють склад державних службовців, особливо категорії А, ті, в свою чергу, змінюють службовців категорії Б;

- посадові інструкції, робота посадовців за якими не дає змоги проявляти здатність державного службовця до самореалізації, в повній мірі розкрити свої можливості до лідерства;

- відсутність ділової комунікації між керівникамиі підлеглими. Багато керівників не зацікавлені у розвитку своїх співробітників;

- обрання за «прозорим» конкурсом на керівні посади в органи державної влади людей 3 «вулиці», які жодного дня не працювали на державній службі чи в органах місцевого самоврядування і відразу ототожнюють свою посаду як лідер колективну, але, слід розуміти, якщо ти прийшов керувати новою групою людей - ти починаєш все спочатку. Одна справа отримати керівну посаду, інша - заслужити у своїх підлеглих довіру, побудувати довірливі відносини і отримати можливість керувати колективом. При цьому самому потрібно цілеспрямовано, продуктивно працювати, стати керівником команди, вміти згуртовувати людей, пропонувати нові ідеї.

Завдання керівника державної установи в умовах невизначеності, в умовах коли неможливо щось планувати на найближчу перспективу, створити такий морально-психологічний клімат у колективі де людина була б задоволена роботою, могла займатися саморозвитком і досягала своїх цілей. Але, нажаль, у більшості випадків на державній службі панує ідеологія знецінення людини, знецінення професіоналів. На державну службу беруть людей за партійною ознакою, за квотним принципом, людей, яким довіряє вище керівництво. Багато розмов та дискусій нині точиться у наукових кулуарах, але грунтовних досліджень в цьому напрямі як не було так і немає, непоправної шкоди державній службі нанесла так звана люстрація із запровадженням у 2014 році Закону України «Про очищення влади». Тисячі професіоналів, які сумлінно працювали на державу, були змушені піти. Ні політичної, ні юридичної відповідальності за нанесення шкоди державному управлінню ніхто не поніс. 
Наш досвід свідчить, що якщо б була передбачувана ситуація хоча б на п'ять років, то частина державних службовців та працюючих в органах місцевого самоврядування змогли застосувати елементи формального лідерства.

Аналіз останніх досліджень і публікацій. Проведений аналіз наукових досліджень, що стосується лідерства в державному управлінні досить таки великий. Питання пов'язані з вітчизняною тематикою висвітлені у роботах О. Руденко, Л. Столяр (лідерство у державному управлінні); І. Грищенко, Л. Акімової, С. Калашнікової, (підготовка управлінців-лідерів), В. Гошовської, В. Бебіка, М. Гаврилюка, Л. Приходченко, В Ліпінцева.

Формулювання цілей статті (постановка завдання). Враховуючи наукові розробки та публікації, слід зазначити, що проблемним питанням залишається формування сучасного лідера, розвиток у нього необхідних знань, умінь, розвинення лідерських якостей державних службовців та посадових осіб місцевого самоврядування, що зумовлює подальші дослідження цієї проблематики.

Виклад основного матеріалу дослідження. За сучасних умов децентралізації $є$ нагальна потреба в певному переформатуванні всієї системи державного управління та місцевого самоврядування в Україні, вимагає впровадження в діяльність цих органів нових методів управління заснованих на лідерстві. Законодавством не закріплені вимоги до професійно-психологічних якостей державних службовців та посадових осіб місцевого самоврядування України, що призводить до того, що ключові суб'єкти державного управління та місцевого самоврядування, які мають поєднувати в собі якості керівника і лідера, у більшості випадків не готові до лідерства: не мають відповідних знань та вмінь щодо його формування й розвитку.

Саме лідерство як феномен управління групою, при правильному його застосуванні, може забезпечити результативність та спрямованість на досягнення спільних цілей. Тому державні службовці та посадові особи місцевого самоврядування зобов'язані постійно розвивати й удосконалювати свою лідерську компетентність. Саме вона допоможе їм стати реальними лідерами не лише для свого 
підлеглого колективу як творчої команди, а й для жителів громади своїх надійних союзників та партнерів, зацікавлених у щоденній співпраці щодо вирішення їх нагальних проблем.

Уряд України продовжує модернізувати свій підхід до управління людськими ресурсами на державній службі та службі в органах місцевого самоврядування з метою приведення їх у відповідність до принципів та стандартів Європейського Союзу та євроатлантичної спільноти. Один 3 ключових аспектів цієї модернізації стосується розвитку лідерів - керівників усіх рівнів на державній службі та службі в органах місцевого самоврядування, й особливо - вищого корпусу, які повинні бути спроможними та відповідальними за впровадження змін в процесі реформування державного управління. Керівники на державній службі та в органах місцевого самоврядування мають відігравати провідну роль під час реформ, бути іiі провідниками, лідерами. Якість лідерства є фундаментом для подальшого успіху. Якщо керівники не приділятимуть належної уваги реформі, то таке ж ставлення до неї буде і у політиків, громадськості [1].

Важливим завданням у сфері здійснення системних реформ державної служби має бути розмежування посад на політичні та адміністративні, такі зміни призведуть до подальшого розвитку професійної, етичної та політично виваженої державної служби. Набір лідерських компетенцій має забезпечити різницю між вище зазначеними посадами через визначення очікуваних вимог які висуваються до державних службовців - тобто тих, хто обіймає адміністративні посади. Надзвичайно важливо, щоб керівники на державних посадах володіли низкою вмінь та навичок за для підтримки та подальшого розвитку інституту державної служби. Реалізація системних якостей які спонукають до лідерства $\epsilon$ неодмінною умовою та важливою запорукою подальшого розвитку вітчизняної державної служби.

Протягом останніх років опубліковано низку робіт вітчизняних вчених та фахівців з проблематики місцевого самоврядування та лідерства. У теорії державного управління термін «лідерство» розглядається як управлінські взаємовідносини між керівником 
і підлеглими, засновані на ефективному поєднанні різних джерел влади і спрямовані на спонукання людей працювати на досягнення поставлених цілей $[3 ; 4]$.

У своїх дефініціях лідерства багато авторів намагались чітко сформулювати той особливий компонент, який вносить сам лідер. Д. Катц та Р. Кан розглядають лідерство як «елемент, який справляє вплив і проявляється незалежно від механічного виконання повсякденних доручень» [5].

Р. Кричевський сприймає лідерство через вплив стосунків у процесі взаємодії, що грунтуються на особистісних характеристиках, де простежується факт домінування і підкорення [6, с. 303].

Відповідно до Енциклопедичного словника 3 державного управління, лідерство включає в себе поняття «керівник-лідер», «державний службовець-лідер». Ці феномени, а саме керівник і лідер, у результаті розвитку публічно-управлінської діяльності постійно піддаються процесу синтезування. На думку дослідників C. Гайдученко та С. Чернова, на попередніх етапах ключова управлінська проблема полягала у встановленні конструктивного співробітництва між офіційними керівниками, 3 одного боку, i лідерами робочих груп та трудових колективів - 3 іншого, а нині в діяльності успішного управлінця стає нормою суміщення функцій керівника 3 роллю лідера. Дедалі, поняття «керівництво» поступово замінюється поняттям «лідерство», оскільки реальне й ефективне управління організацією забезпечується не стільки авторитетом посади, скільки авторитетом особистості керівника, його лідерськими здібностями [7].

О. Віханський доводить, що «лідерство - це специфічний тип відносин управління, заснований на соціальному впливі, а точніше взаємодії в організації. Він розглядає лідерство як тип управлінської взаємодії (між лідером і послідовниками), заснований на найбільш ефективному для даної ситуації поєднанні різних джерел влади $і$ направлений на спонукання людей до досягнення загальних цілей» [8, с. 387].

М. Альберт, Л. Едінгер, М. Мескон, Ф. Хедоурі розуміють «лідерство як вплив на інших людей». Зазначені автори визначають 
такі вимоги впливу: «1) повинен бути постійним; 2) вплив лідера має грунтуватися не на безпосередньому використанні сили, а на авторитеті або визнанні правомірності керівництва; 3) керівництво лідера має поширюватися на весь колектив (організацію); 4) лідер повинен мати явний пріоритет у впливі. Таким чином вони наполягають на визнанні формального управлінського статусу лідера» [9, с. 43].

Для більш детального розуміння визначення поняття лідерства від зарубіжних та вітчизняних науковців розглянемо табл. 1.

Таблиця. 1

Значення лідерства від різних авторів

\begin{tabular}{|c|c|}
\hline $\begin{array}{c}\text { Автор } \\
\text { визначення }\end{array}$ & Сутність визначення \\
\hline Р. Такер & $\begin{array}{l}\text { «щось значно більше, ніж прийняття } \\
\text { управлінських рішень, це вплив на розум та } \\
\text { енергію тих людей, які мають зіграти свою } \\
\text { роль в тому чи іншому процесі» [10] }\end{array}$ \\
\hline Р.Кричевський & $\begin{array}{l}\text { «вплив стосунків у процесі взаємодії, } \\
\text { що гонунуються } \\
\text { характеристиках, де простежується факт } \\
\text { домінування і підкорення» [6] }\end{array}$ \\
\hline В. Шатун & $\begin{array}{l}\text { «мистецтво впливу на людей, прагнення } \\
\text { надихнути іх на те, щоб вони за власним } \\
\text { бажанням прагнули досягнути цілей» }[11]\end{array}$ \\
\hline Д. Ольшанський & $\begin{array}{l}\text { «специфічний феномен, який виникає при } \\
\text { взаємодії лідера і ведених ним осіб, на стику } \\
\text { двох проблем: психології окремої особистості } \\
\text { i психології груп, малих і великих» [12] }\end{array}$ \\
\hline Р. Мертон & $\begin{array}{l}\text { «лідерство як міжособистісні відносини, що } \\
\text { існують між співробітниками, які виконують } \\
\text { роботу не тому, що вони зобов’язані, а тому, } \\
\text { що вони хочуть їі виконувати» [13] }\end{array}$ \\
\hline Г. Ашин & $\begin{array}{l}\text { «здатність впливати на людей швидше } \\
\text { емоційними закликами, ніж використанням } \\
\text { авторитету» [14] }\end{array}$ \\
\hline
\end{tabular}


продовження таблищі 1

\begin{tabular}{|c|c|}
\hline Т. Пітерс & $\begin{array}{l}\text { «мистецтво, а не наука. Лідерство - } \\
\text { це таємниця Людської душі. Лідерства }- \\
\text { спрямовуюча діяльність» [15] }\end{array}$ \\
\hline Ф. Енан & $\begin{array}{l}\text { «процес прямої взаємодії, результатом } \\
\text { якої є вплив індивіда за допомогою мови } \\
\text { на поведінку інших, що спонукає ї до } \\
\text { досягнення певної мети» }[16]\end{array}$ \\
\hline О. Дармограй & 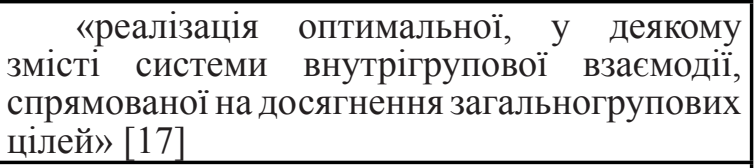 \\
\hline $\begin{array}{l}\text { Л. Сергеєва, } \\
\text { В.Кондратьєва, } \\
\text { М. Хромей }\end{array}$ & $\begin{array}{l}\text { «істотна складова частина діяльності } \\
\text { менеджера, пов’язана } 3 \text { цілеспрямованим } \\
\text { впливом на поведінку окремих осіб чи } \\
\text { робочої групи; інструментами такого } \\
\text { впливу виступають навички спілкування } \\
\text { й особистісні якості менеджера, які } \\
\text { відповідають зовнішнім і внутрішнім } \\
\text { потребам групи» [18] }\end{array}$ \\
\hline С. Лозниця & $\begin{array}{l}\text { «здатність впливати на індивідуумів і } \\
\text { групи людей,щоб спонукати їх працювати } \\
\text { для досягнення цілей» [19] }\end{array}$ \\
\hline Р. Кричевський & $\begin{array}{l}\text { «вплив стосунків у процесі взаємодії, } \\
\text { що грунтуються на особистісних } \\
\text { характеристиках, де простежується факт } \\
\text { домінування і підкорення» [20] }\end{array}$ \\
\hline Р. Дафт & $\begin{array}{l}\text { «взаємовідносини між лідером і членами } \\
\text { групи, які чинять вплив один на одного } \\
\text { й спільно прагнуть до реальних змін і } \\
\text { досягнення результатів, що відображають } \\
\text { загальні цілі» [21] }\end{array}$ \\
\hline
\end{tabular}

Джерело розробки авторів. Американський вчений П. Друкер вважає, що керівником-лідером можна вважати такого керівника, який має прибічників, прихильників, людей,які його підтримують $i$ слідують за ним із великим бажанням і вірою в нього. Люди ідуть за таким керівником за власним бажанням, а не тільки через те,що той $є$ керівником. Успішний лідер, на думку П. Друкера, «не завжди є тією 
особистістю, яку всі люблять або якою захоплюються. Лідерство не означає популярності. Лідерство, вважає вчений, то в першу чергу результати дій,які для всіх відкриті. Саме вони демонструють іншим приклад. Лідерство не виникає 3 посади, привілеїв, титулів чи грошей. Лідерство - то велика відповідальність» [2].

Ю. Платонов зазначає, що «феномен лідерства, відносини лідерства виникають завжди, коли групі людей доводиться вирішувати проблеми, які зачіпають інтереси всіх або більшості членів групи. Найбільш помітними лідерські відносини стають у тому випадку, коли перед групою постають завдання розподілу ресурсів (ресурси в цьому контексті розуміються в широкому аспекті: матеріальні, фінансові, продовольчі, інформаційні тощо)» [22].

Посада державного службовця надає керівникові необхідні умови бути лідером колективу, але фактично він таким не стає, хоча має всі можливості. Якщо керівник в державній службі налаштує роботу колективу у правильне русло і його робота буде ефективною, в цьому випадку даний керівник стане лідером для свого колективу.

Словник термінів «Лідерство в місцевому самоврядуванні» подає лідерство як:

- «керівне становище соціальної групи, особистості, партії, держави;

- процеси внутрішньої самоорганізації та самоуправління групи, зумовлені індивідуальною ініціативою їхніх членів;

- процес, за допомогою якого одна людина справляє вплив на іншу чи на групу людей;

- система міжособистісних відносин в організації між колективом та лідером, особистісний вплив якого дає йому змогу відігравати провідну роль у ситуаціях, які стосуються інтересів та характеру діяльності всього колективу. Лідерство передбачає значно більшу міру відповідальності в досягненні цілей, ніж того вимагають загальноприйняті норми. Лідерство стимулює постійний розвиток в особистості інтелектуальних здібностей, творчого мислення, випереджального уявлення, стратегічного мислення, сильної волі та ін., що дає можливість формулювати нові цілі, висувати нові ідеї» [23]. 
Лідерство на державній службі - це управлінський статус особи, що наділена спеціальними якостями, які допомагають їй у процесі групування людей для визначення та досягнення спільних цілей.

На ефективність лідерства впливають особистісні якості, потреба в яких зумовлена не тільки специфікою роботи й особливостями поставлених завдань та цілей. При цьому необхідне поєднання особистісних рис із професійною компетентністю.

Визначення та розвиток лідерських компетенцій на державній службі актуальне у зв'язку 3 необхідністю оперативного реагування керівних працівників органів влади на вимоги та виклики, що виникають у зв'язку 3 процесами суспільної трансформації,економічного розвитку, європейської інтеграції нашої держави.

Профілі компетенцій лідерства сприятимуть розвитку сучасної культури урядування, відповідальності керівників усіх рівнів за управління людськими ресурсами, реалізації нових принципів державної служби [2].

Основним підходом щодо розвитку керівників-лідерів на державній службі $є$ наявність загальних рамок щодо розвитку лідерства, визначених на основі чітко окреслених профілів компетенцій лідерства.

Існує чіткий зв'язок між роботою, що виконує особа на посаді, яку займає, та навичками, які вона потребує для виконання цієї роботи. Тому профіль компетенцій - це набір компетенцій, що безпосередньо стосується певної діяльності, яка має виконуватися. Профіль компетенцій лідерства $є$ описом набору компетенцій та відповідно пов'язаної з ними поведінки, що безпосередньо стосується керівних кадрів на державній службі для забезпечення реалізації ними функцій лідерства, сприяння реалізації реформ та приведенню державної служби до стандартів Свропейського Союзу [2].

Профілі компетенцій лідерства використовуються у багатьох сферах управління людськими ресурсами: при доборі та просуванні по службі, оцінці діяльності, плануванні кар〉єри та розвитку, плануванні людських ресурсів. Профілі компетенцій лідерства $\epsilon$ основою для професійного розвитку державних службовців 
для визначення особистих потреб у навчанні та вдосконалення навчальних програм і підходів до підвищення кваліфікації.

До загального набору якостей лідера відносять: чесність, високий рівень інтелекту, зовнішність, ініціативність, дисциплінованість, високий рівень впевненості в собі, мудрість, цілеспрямованість, комунікабельність та відкритість, інтуїцію, інтелігентність тощо [24].

Зарубіжні дослідники I. Беніс, Р. Стоділ «серед загальних якостей лідера,зокрема, виокремлюють: цілісність, допитливість, відвагу, упевненість, активність, рішучість, відповідальність, толерантність тощо» $[22 ; 25]$.

Українська дослідниця Л. Орбан-Лембрик відносить до особистісних якостей лідера ще добру фізичну форму і здоров'я. «Здорові люди, - вважає вона, - продуктивно працюють, їм властиві творчість, комунікабельність,почуття гумору, критичність, здатність виявляти нові резерви ефективності своєї життєдіяльності» [26].

Окремі дослідники (I. Романчук, I. Карнаух) виокремлюють ще одну групу якостей лідера - це професійні якості. Професійні якості, на їхню думку,це ті, «які набуваються індивідом протягом усього життя у процесі пізнання світу, копіткої роботи над собою та виконання своїх службових обов'язків і функцій» [27]. Ці дві групи якостей (професійні та особистісні), на нашу думку, складають професійні компетенції лідера (лідерства).

Як визнано науковцями, модель будь-якої компетентності складається 3 ключових і посадових профілів компетентності та профілю компетентності завдання. Модель компетентності лідерства керівника в цьому сенсі не є виключенням.

Графічний вигляд моделі компетентності лідерства керівника, як і будь-якої компетентності, має форму піраміди, яка спирається на профіль ключової компетентності лідерства, а завершується профілем компетентності лідерства при виконанні завдання. Профіль ключової компетентності лідерства керівника охоплює всі необхідні для успішного керівництва характеристики лідерства, які сприяють формуванню та підтримці організаційної культури, рівноправному i зацікавленому співробітництву організації зі службовцем, виконанню місії організації та досягненню усіх цілей 
тощо. До цього профілю доцільно віднести такі характеристики рівня лідерства керівника [27]:

- «безперервний особистий розвиток - здатність до самооцінки, самонавчання, саморозвитку;

- високий рівень управлінської культури - здатність до управління змінами, інформацією, ризиками, конфліктами, стресом, робочим часом, професійним розвитком підлеглих, ресурсами тощо;

- аналітичне мислення - здатність до систематичного аналізу ситуації та проблем шляхом збору і систематизації інформації (з використанням широкого набору джерел інформації), визначення ключових проблем та причинно-наслідкових зв'язків, пошуку різних шляхів розв'язання проблем;

- бачення перспективи діяльності-спроможність визначити та описати бажаний для організації або підрозділу стан у майбутньому, належним чином інформувати працівників, розробляти плани та стратегіï, які сприятимуть його досягненню;

- делегування повноважень - спроможність надавати повноваження співробітникам, чітко інформуючи про параметри делегування (наприклад, необхідні дії чи терміни) та контролюючи виконання делегованих завдань;

- результативна комунікація - вміння використовувати усні та письмові форми комунікації з урахуванням потреб підлеглих та партнерів для інформування, переконання, здобуття підтримки, впливу, пошуку компромісу та досягнення домовленості; вміння ведення обговорень та переговорів; знання процедур та механізмів діяльності органів влади; знання суспільно-політичних та економічних тенденцій, які відбуваються в Україні та поза іiі межами;

- креативність - здатність генерувати нові ідеї (послуги, підходи, методи), створювати умови для співробітників, які сприяють творчому мисленню, новим ідеям та бажанню їх втілювати;

- раціональне управління ресурсами - здатність раціонально управляти людськими, фінансовими та матеріально-технічними ресурсами підрозділу, узгоджуючи пріоритети та ресурси, забезпечуючи ефективність поточної діяльності» [27]. 
Посадовий профіль компетентності лідерства керівника включає в себе всі необхідні для успішного керівництва характеристики лідерства, які сприяють успішному виконанню конкретних посадових обов'язків, пов'язаних із специфікою професійної діяльності та iї пріоритетами. До них можна віднести:

- високий рівень планування (стратегічного, поточного, кадрового, навчання, впровадження інноваційних технологій тощо);

- високий інформаційний рівень;

- найвищий рівень контролю;

- високий рівень співробітництва 3 підлеглими, суміжниками та спілкування з громадськістю;

- відповідний рівень звітності вищому керівництву (вчасність, правдивість, об'єктивність, достатність тощо).

До ключових компетенцій можна віднести: орієнтацію на результат - можливість перебирати на себе відповідальність, системно та зважено діяти згідно визначених цілей, маючи на меті досягнення запланованих результатів в хист до керування наявними ресурсами, враховуючи потреби та завдання організації; здатність аналітично мислити та об'єктивно сприймати, аналізувати та розміщувати інформацію яка допомагає узагальненню отриманої інформації, враховувати головні деталі та перспективи. Серед інших компетенцій, що сприяють отриманню результату є вміння визначити проблему, показати ступінь її важливості та причинно - наслідкові зв'язки. Також для реалізації цієї компетенції необхідно створити основу для розвитку довгострокового бачення, послідовні дії та координацію; можливість керівників притримуватись системного стратегічного підходу, щодо управління людськими ресурсами та персоналом, брати на себе відповідальність за їх планування, кадровий добір, розвиток їх можливостей та організацію справ на засадах поточних та майбутніх потреб установи, мотивація до результативної діяльності, констатація ролі працівників, щодо їх особистого внеску у стан справ установи та підтримка належних умов праці. Також важливу роль у низці ключових компетенцій відіграє ефективна комунікація яка слугує запорукою ефективної та результативної процедури обміну інформацією як у горизонтальній 
так і у вертикальній площині, за для досягнення порозуміння та підтримки у процесі реалізації визначених цілей організації; вміти логічно, чітко та доступно сформулювати власну точку зору відповідно до потреб колективу, у різних умовах із використанням різноманітних форм видів та засобів комунікації; вміння слухати та забезпечувати зворотній зв〉язок.

Важливою складовою лідерства в державному управлінні $є$ компетентність державного службовця, орієнтована на виконання функцій і завдань державного управління.

Професійні компетенції державних службовців мають свої особливості, свою специфіку, а саме: персональна відповідальність за прийняті управлінські рішення, їхня висока соціальна значущість, необхідність мати широкий спектр знань у різних галузях. Важливо, що професійні компетенції державних службовців мають публічний ефект і вони оцінюються суспільством, громадянами.

Враховуючи це та спираючись на європейський досвід, варто виокремити професійні компетенції лідерів у державному управлінні 3 метою створення профілів компетенцій лідерства, для врахування у процесі навчання управлінців, для здійснення оцінювання їх як лідерів тощо.

Таким чином, на підставі проведеного теоретичного дослідження нами виокремлені професійні компетенції лідерства в державному управлінні, які ми класифікуємо за такими групами:

- харизматичні(увагадосвогоздоров'яідозбереженняздоров'я людей, сміливість, мужність, доброчесність, стресостійкість, витримка, впевненість у собі, ентузіазм, захоплення, переконання, здорові амбіції, орієнтація на досягнення результату, асертивність уміння тактично обстоювати свою точку зору, упертість і твердість, інтелект та відвага, адекватність, здатність експериментувати і не боятися ризикувати; уміти бути імпровізатором);

- комунікативні (здатність переконувати i мотивувати співробітників,уміти налагоджувати співпрацю між відомствами, між керівниками різних та зрозумілі завдання перед підлеглими, здатність переконливо говорити й уважно слухати інших, мати почуття гумору, увага і повага до людей); 
- організаторські (уміння працювати в команді, здатність брати на себе відповідальність, спрямовувати людей на досягнення тривалих і перспективних цілей та здійснення реформ, уміти правильно розподілити на посади підлеглих відповідно до їхніх здібностей та заохочувати їх до праці,створювати умови для того, щоб кожний працівник відчував свою значущість і вартість, уміти бачити i розкривати потенціал кожного працівника і відповідно використовувати на користь загальних результатів, уміння вести за собою, уміти управляти ситуацією, демонструвати спокій i впевненість,створювати добрий мікроклімат, уміння мобілізації людей на постановку цілей, виконання планів i досягнення результатів);

- «синдром хамелеона» (еластично пристосовуватися до змінного оточення, бути відкритим до змін, мати такт i дипломатичний талант, бути делікатним, не ображати людей, не критикувати на людях, більше хвалити співробітників навіть за маленький успіх, здатність до взаємодіi);

- адміністративні (креативність, здатність до сприйняття нових ідей і продукування своїх ідей, уміти передбачати, розпоряджатися, узгоджувати,приймати рішення, уміти координувати, делегувати, контролювати, бути завжди поінформованим, уміти розв'язувати конфлікти, уміти їх передбачати i не допускати, проявляти спроможність дотримуватися послідовного стратегічного курсу щодо управління людськими ресурсами, управління інноваціями);

- інтелектуальні (здатність генерувати ідеї, будувати стратегічні плани, стратегічно й аналітично мислити, уміти уважно спостерігати іробитиз цього свої висновки, здатність учитися новому, бути кваліфікованим у своїй сфері діяльності, уміння вчитися, вдосконалюватися, працювати над собою,здатність до самоаналізу, панорамність мислення, здатність до інновацій,мобільність, ефективне використання інформаційної техніки;

- управлінської майстерності (орієнтація на результат у проведенні реформ, обізнаність у своїй справі, здатність впливати на мислення й поведінку підлеглих, уміння розробляти рішення, володіння управлінською культурою, здатність управляти особистою 
ефективністю, навички презентування себе і колективу, здатність до взаємодії, відстежування змін, кризи,реагування на них оперативно, розроблення рекомендації та стратегії, враховуючи потреби зацікавлених сторін, уміння закладати основи для роботи,створюючи коаліції з головними дійовими особами, здатність домовлятися й адаптуватися, уміння готувати резерв кадрів, уміти оточувати себе розумними, кваліфікованими, перспективними помічниками i співробітниками,уміння оцінювати ефективність роботи підлеглих, делегувати повноваження тощо);

- поведінкові (індивідуальний підхід до підлеглих, уникнення конфліктів - ніколи не звільняє конфліктну особу з посади без ㄲi згоди, бо це може викликати конфлікт і нестабільну ситуацію в колективі: талановиту конфліктну особу підтримує, шукає до неї підхід, використовує ії̈ потенційні можливості на користь організації, нестабільну особу переводить на іншу ділянку роботи;дослухається до думки підлеглих, але рішення приймає своє і за нього відповідає, у поразках ніколи не звинувачує підлеглих, спирається на власний авторитет, має здатність до взаємодії, аналізує, мотивує та переконує підлеглих працівників, проявляє швидку реакцію на прийняття рішень, уміння обстоювати свою думку).

Зауважимо, що запропонована класифікація $є$ умовною, бо одні й ті самі компетенції можуть перегукуватися з тією чи іншою групою або їх може бути недостатньо.

Керівна ланка у системі державної служби має впливову роль у розробці та запровадженні системних змін та реформ на державній службі. Виходячи 3 цього надважливим $є$ те, що на державній службі мають бути створені сприятливі умови для здобуття освіти та саморозвитку з метою системного професійного зростання керівників які мають лідерські якості. Отже головним набором лідерських компетенцій у системі державної служби України означимо наступні: вміння керівника результативно керувати, наявність аналітичного складу мислення та стратегічного планування, навички якісної (усної та письмової) комунікації, вміння брати відповідальність за керівництво людськими ресурсами (рис. 1) 


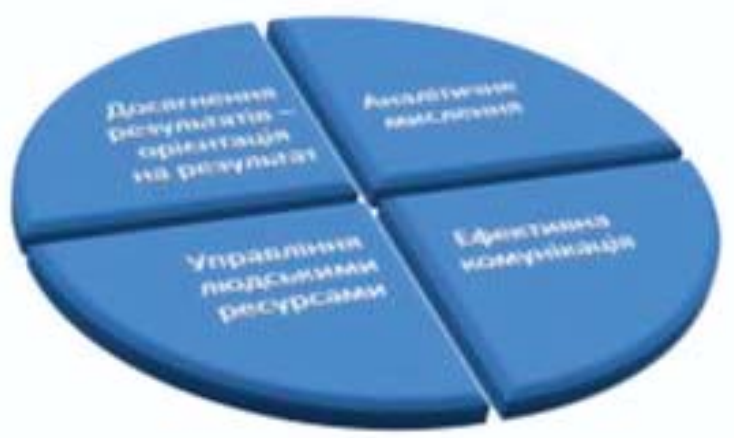

Puc. 1. Ключові компетенції лідерства

Акцентація на досягненні окреслених результатів роботи напряму залежить від сподівань та очікувань, щодо результативності та якості діяльності державних службовців, успішного запровадження реформ, розвитку дієвої державної служби яка має змогу надати відповідь на головні виклики суспільства та забезпечити високий рівень якості послуг для населення.

Актуальною $є$ можливість обгрунтування роботи та додержання затверджених стратегій поступального розвитку на засадах аналітики та планування, розробка політики, яка нині є найголовнішою функцією державних службовців, з метою забезпечення поступовості дій та вчинків, що сприятимуть вирішенню нагальних суспільних потреб.

Говорячи про ефективну комунікацію, варто надати її визначення яке на нашу думку полягає у можливості ефективного обміну досвідом та інформацією як у горизонтальній так і у вертикальній площині і має на меті підтримку організації на шляху запровадження іiі власних цілей; з іншої сторони це вміння конкретно та чітко викласти власну точку зору з урахуванням потреб та бажань громадян, за різних умов та запровадженням різних форм (способів) комунікації; це здатність до забезпечення зворотнього зв'язку та вміння почути інших. Безперечно необхідним є розуміння керівниками власної відповідальності між структурами (органами), співпраці організацій у 
горизонтальній та вертикальній площинні, між керівниками різних рівнів та колегами 3 метою додержання принципів прозорості та ефективності, спільної координації та підтримки в процесі досягнення цілей.

Отже можемо стверджувати, що лідерство то є один із дієвих механізмів реалізації відносин у людському середовищі: (соціальні групи, інститути суспільства). Сутнісний зміст його полягає у пануванні відносин та підлеглості. Лідерство може проявлятись не лише як функція особистості або групи, а й як результат впливу різнопланових чинників та ситуацій. Можемо стверджувати, що реалізація основних напрямків лідерства державних службовців $є$ пріоритетною і має набути обов'язкового характеру для посадових осіб та представників місцевого самоврядування та стати основою безперервного процесу з удосконалення їх професіоналізму.

Запорукою результативності багатьох реформ в Україні $\epsilon$ наявність у багатьох керівників державних органів та установ різних форм власності можливостей реалізовувати лідерські якості в управлінні, запроваджувати сучасне організаційне середовище в якому створюються умови підтримки та розвитку організаційної поведінки яка в кінцевому доробку надасть населенню високу якість адміністративних послуг.

Відповідно до завдань які зафіксовані у Стратегії державної кадрової політики Національне агентство України 3 питань державної служби (НАДС), яке $є$ виконавчим органом влади розробило рекомендації в яких чи не вперше в історії управлінської науки в Україні на документальному рівні зафіксовано визначення терміну «лідерство» та сформульовано рекомендації, щодо поведінки керівника на засадах лідерства в органах влади. А саме: лідерство визначається як «здатність керувати і заохочувати колег, підлеглих і партнерів діяти для досягнення цілей» [30].

Згідно запропонованих НАДС рекомендацій лідер має відповідати наступним вимогам:

- має навички передбачати події спільно 3 колегами та підлеглими, розробляти концепцію або стратегію, щодо запобігання різних проблем у майбутньому; 
- доводить власні міркування підлеглим та колегам, за для активізації творчого настрою, підвищення працездатності та згуртованності колективу;

- запроваджує власні креативні думки та ідеї за для досягнення спільного результату;

- уявляє повноту спільного розуміння та продовжує накопичувати інформацію з метою реалізації власних навичок та умінь;

- створює у колективі умови за для готовності до змін;

- підтримує рішення підлеглих у прийнятті змін, тим самим маючи вплив на загальне сприйняття із використанням підтримки колективу;

- використовує власні управлінські методи та засоби залежно від ситуаціі;

- розробляє власні завдання 3 метою всебічного розвитку працівників, створює різні ситуації за для підвищення досвіду та навичок працівників;

- надає можливість працівникам самим розв’язувати проблеми, не втручаючись в ухвалення рішень;

- сміливо та зважено демонструє власні почуття та переконання, враховуючи думку колективу.

На нинішньому етапі принципові положення лідерства виводяться 3 низки функціональних характеристик лідера: готовність до ризику, вміння надихнути, делегування повноважень, лідер як приклад наслідування, цінування індивідуального внеску членів команди і відзначення досягнень [31].

Умовно, теоретичним базисом (базовими елементами) лідерства можливо назвати елементи концепції «7-С»: стратегія, структура, системи і процедури роботи (закріплені у відповідних інструкціях), стиль, склад персоналу, сума навичок і сумісно сповідуванні персоналом цінності [32].

Для повноцінної реалізації лідерського потенціалу держаної служби необхідно впроваджувати конкретні моделі лідерства.

На сьогоднішній день сформовано досить багато теорій лідерства [33; 34; 35]:

1. «Теорія соціального обміну (Дж. Хоманс) - виникнення 
лідерства пов'язується 3 існуванням психологічного обміну цінностями (значущими особистісних якостями, вміннями,знаннями, досвідом.

2. Теорія людських ролей (Р. Бейлс) - обгрунтовує розподіл керівників за типами лідера-професіонала, котрий займається розв'язанням робочих питань та «емоційного лідера», котрий урегульовує людські стосунки у колективі.

3. Теорія харизматичного лідера (Дж. Конгер, Р. Хаус, Б. Шамір) - обгрунтовує лідерство наявністю певних якостей,що у сукупності формують харизму лідера - властивість, яка викликає у послідовників довіру та готовність слідувати за лідером.

4. Інтерактивна теорія - припускає можливість будь-якого члена колективу стати лідером у залежності від особистих властивостей цього та інших членів колективу, ситуації та мети, що стоїть перед колективом.

5. Синтетична теорія - основним завданням лідера вважається організація (синтез) міжособистісних стосунків у колективі.

6. Ситуативна теорія (Ф. Фідлер) - лідерство виникає як реакція на конкретну ситуацію, вирішення або ефективна поведінка в умовах якої вимагають певного комплексу особистісних рис, умінь, навичок, володіння специфічними управлінськими методами та прийомами.

7. Теорія рис (Р. Манн, Р. Стогділл) - розглядає лідера як сукупність певних психологічних якостей, наявність яких сприяє набуттю індивіда статусу лідера, і наділяють його здатністю приймати владні рішення відносно інших людей.

8. Поведінковий підхід (Р. Блейк, К. Левін) - результативність управління визначається не стільки особистісними якостями, стільки тим, як лідер поводить себе з послідовниками.

9. Адаптивний підхід (Т. Мітчел, П. Херсі) - ефективність лідерства визначається здатністю адаптуватись до швидко змінюваних обставин.

10. Системна теорія (М. X'юстон) - розглядає процес організації міжособистісних відносин у групі, а лідера - як суб'єкта управління цим процесом» $[33 ; 34 ; 35]$.

Для того, щоб на державній службі керівникам бути успішними 
лідерами, вони мають по - перше бути активними ініціаторами системних змін та перетворень у державі, тримати у своєму арсеналі фахові та професійні компетенції, що мають лідерське спрямування, постійно отримувати нові знання та підвищувати кваліфікацію 3 цього напрямку.

Час не стоїть на місці. Багато державних службовців, незважаючи на всі проблемні питання, бажають оновлювати, поглиблювати свій професійний рівень компетентності через отримання другої вищої освіти, підвищення кваліфікації, стажувань. В цьому контексті надважливим є умови, що мають бути створені на державній службі для навчання, розвитку та підтримки лідерських якостей керівника.

Під час виконання аналізу, щодо наявності у керівника державної служби лідерських навичок варто керуватися розробленою методикою, яка у кінцевому додатку дасть змогу виявити як слабкі так і сильні сторони лідера, сприятиме їх подальшому удосконаленню. Вище зазначена методика має на меті вивчення моделі успішного керівника в державному органі, яка включає в себе декілька етапів, що дає змогу виявити проблемні аспекти керівника державної служби.

На першому етапі відбувається процедура анкетування тобто отримання даних шляхом письмового опитування у вигляді відповідей, до яких вже зроблені питання та відповіді. Ця анкета містить питання у вигляді 5 блоків із загальною кількістю 50 питань в анкеті. Усі блоки відповідають за конкретну лідерську якість, що має бути наявною у успішного керівника державної служби.

Анкетування надає інформацію яка показує необхідні якості на певному етапі. Ця інформація сприятиме визначенню потенціалу керівника державної служби, його лідерських якостей, що підвищать цей потенціал.

Під час дослідження експертним методом було окреслено коефіцієнт значущості кожного блоку анкети, які складаються 3 блоків, що мають назви лідерських якостей державного управлінця. В той же час рекомендовано користуватись переліком лідерських якостей, що зазначені у таблиці 2, які на думку авторів, найповніше розкривають особистість державного службовця як лідера. 
Таблиця. 2

Основні лідерські якості державного службовця

\begin{tabular}{|c|c|c|}
\hline $\begin{array}{c}\text { Позна- } \\
\text { чення }\end{array}$ & Лідерські якості керівника державної служби & $\begin{array}{c}\text { Крите- } \\
\text { piï }\end{array}$ \\
\hline $\mathrm{X} 1$ & Відповідальність & \multirow{5}{*}{$\begin{array}{c}\text { Від 0 } \\
\text { до } 0,2\end{array}$} \\
\hline $\mathrm{X} 2$ & Знання законодавчої бази держави & \\
\hline $\mathrm{X} 3$ & Рівновага між кар`єрою та особистим життям & \\
\hline $\mathrm{X} 4$ & Готовність до змін & \\
\hline $\mathrm{X5}$ & Управління людськими ресурсами & \\
\hline
\end{tabular}

Відповідальність - свідоме ставлення керівника до своїх обов 'язків. Являється одним із п'яти найголовніших якостей, які були виділені. Відповідальний керівник це та особа, яка викликає довіру, отже дуже важливо, щоб керівник на державній службі був відповідальною особою за себе і за власний колектив.

Отримання освіти у профільних вищих навчальних закладах це надає можливість оволодіти знаннями у сфері законодавства та $€$ запорукою професійного зростання, саморозвитку. Володіння нормативно - правовою базою дає змогу керівнику чітко виконувати свої обов язки та не виходити за межі своїх повноважень.

Рівновага між кар єрою та особистим життям є також важливою якістю для лідерства, тому що будь-яка особа, а особливо керівник повинен розділяти особисте життя з роботою, не вносити особисті проблеми до свого колективу та не розголошувати державні таємниці, навіть своїм найріднішим людям, яким він довіряє на сто відсотків.

Вміння реагувати на зміни - це можливість невпинного саморозвитку та самовдосконалення власних навичок та умінь, реалізація себе як у приватному так і у професійному житті. Такі навички сприяють бути гнучким до змін.

Управління людськими ресурсами є важливою складовою лідерських якостей керівника, оскільки керувати людьми має здатність не кожна людина, тому керівник на державній службі повинен розуміти психологію людини та життя. 
Другий етап передбачає оцінку ефективності лідерства, саме через лідерські якості які надають вагомі професійні лідерські компетенції керівникам які обіймають посади на державній службі категорії А і Б. Щоб визначити рівень лідерського потенціалу керівника нами окреслено набір якостей які визначають цей потенціал, різних категорій та рангів.

На підставі проведених досліджень запроваджено для розрахунку коефіцієнт лідерства (Кл), цей коефіцієнт складається із суми здобутків якостей керівника які ми визначили, що помножені на критерії їх оцінки які найбільше мають вплив на кожну 3 цих якостей. Модель успішного керівника в державній службі представлені в такому вигляді [36]:

$$
\begin{array}{r}
\text { Кл = a x } \mathrm{X}_{1}+\mathrm{bxX}_{2}+\mathrm{cx} \mathrm{X}_{3}+\mathrm{dx} \mathrm{X}_{4}+\mathrm{exX}_{5} \\
\text { де Кл }- \text { коефіцієнт лідерства; }
\end{array}
$$

$\mathrm{X}_{1}, \mathrm{X}_{2}, \mathrm{X}_{3}, \mathrm{X}_{4}, \mathrm{X}_{5}$ - основні лідерські якості керівника державної служби;

$\mathrm{a}, \mathrm{b}, \mathrm{c}, \mathrm{d}, \mathrm{e}-$ критерії оцінки відповідних якостей керівника державної служби (див. табл. 3) [36].

Таблиця. 3

\begin{tabular}{|c|c|c|c|}
\hline $\begin{array}{c}\text { Позна- } \\
\text { чення }\end{array}$ & \multicolumn{2}{|r|}{ Характеристика } & Критерій \\
\hline \multirow{6}{*}{$\mathrm{a}$} & \multirow{4}{*}{ Судимість } & Наявність непогашеної судимості & 0 \\
\hline & & & \\
\hline & & Наявність погашеної судимості & 2 \\
\hline & & Відсутня судимість & 5 \\
\hline & \multirow[b]{2}{*}{ Відкритість } & $\begin{array}{l}\begin{array}{l}\text { Немає в доступі інформації про } \\
\text { особу }\end{array} \\
\end{array}$ & 1 \\
\hline & & $\begin{array}{l}€ \text { інформація про особу (сторінки в } \\
\text { соц. мережах, телефон на офіційному } \\
\text { сайті та інше) }\end{array}$ & 5 \\
\hline
\end{tabular}

\section{Критерії оцінки лідерських якостей державного службовця}


продовження таблиці 3

\begin{tabular}{|c|c|c|c|}
\hline \multirow{3}{*}{$\mathrm{b}$} & \multicolumn{2}{|c|}{ Стаж роботи в організації } & \multirow{2}{*}{$\begin{array}{c}\text { Кількість } \\
\text { років } \\
\text { Кількість } \\
\text { років }\end{array}$} \\
\hline & \multirow[t]{2}{*}{$\begin{array}{l}\text { Навчання в } \\
\text { університеті }\end{array}$} & Денна форма (магістр) & \\
\hline & & Заочна форма (магістр) & 2 \\
\hline \multirow{3}{*}{$\mathrm{c}$} & \multirow{3}{*}{$\begin{array}{l}\text { Комунікація } \\
\text { та взаємодія }\end{array}$} & Ефективна дія & 5 \\
\hline & & Слабо розвинена & 2 \\
\hline & & Відсутня & 0 \\
\hline $\mathrm{d}$ & \multicolumn{2}{|c|}{ Саморозвиток } & Від 0 до 5 \\
\hline e & \multicolumn{2}{|c|}{ Управління організацією (відділом) та персоналом } & $\begin{array}{c}\text { Кількість } \\
\text { людей у } \\
\text { команді }\end{array}$ \\
\hline
\end{tabular}

В ході даної роботи виділено якості, що на нашу думку, впливають на лідерство керівника державної структури та визначені експертним методом критерії оцінки цих якостей. Відповідно до табл. 3 виділяють такі якості, що впливає на вище зазначені лідерські якості.

Судимість та відкритість впливають на відповідальність керівника, тому вважаємо доцільним визначати критерій «судимість» важливим для визначення відповідальності особи. Людина, яка вчиняла лише один проступок, відповіла за нього перед законом та більше не вчиняла таких вчинків, вважається більш відповідальною ніж особа, яка постійно потрапляє за грати чи сплачує штраф. Особа являється найбільш відповідальною за даним критерієм, якщо вона ніколи не вчиняла правопорушень, що тягне за собою кримінальну чи адміністративну відповідальність. Також одночасно 3 цим критерієм вважаємо за доцільне розглядати критерій «відкритість», який свідчить про те, що керівнику державної служби немає що приховувати від громадян.

Стаж роботи та навчання (ВН3) - дані критерії впливають на знання законодавчої бази,а також інших спеціальних наук, що дозволить керівнику вміло виконувати свої повноваження, передбачати деякі ситуації та діяти по ситуації.

Комунікація та взаємодія впливають на рівновагу між кар єрою та особистим життям. Важливим є те, що керівник прийшов на цю 
посаду завдяки працьовитості, старанності до роботи та готовності до співпраці з людьми.

Саморозвиток пов язаний 3 готовністю до змін. Керівник повинен розуміти, що справжній лідер-керівник повинен постійно удосконалюватися та надихати колег до саморозвитку.

Вміння управляти організацією впливає на ефективність управління людськими ресурсами. Даний критерій залежить від того, скільки людей працює у відділі чи організації, де керує керівник, та визначає продуктивність роботи даного колективу.

За результатами розрахунків можливо визначити, хто iз керівників державної служби наділений найвищим значенням лідерських якостей та як впливає це на його роботу. Державний керівник-службовець 3 вищим коефіцієнтом лідерства є найбільш підходящим та визнаним суспільством успішним керівником, який має достатньо великі переваги в отриманні надбавки до заробітної плати, що буде мотивувати керівника на ще більшу ефективність роботи його та його команди.

Слушна думка науковців які вважають, що «після затвердження «Профілів компетенцій лідерства», очікується, що вони стануть одним 3 ключових елементів щорічного оцінювання діяльності керівників на державній службі в Україні. Іншими словами, керівники мають демонструвати необхідні лідерські компетенції при щоденному виконанні ними своїх функцій / обов'язків, зокрема: слугувати прикладом етичної поведінки та дотримання принципів державної служби, досягати результатів у своєму відомстві, демонструвати аналітичне мислення та ефективну комунікацію, управляти людськими ресурсами тощо. Очікується, що в майбутньому державні службовці при призначенні на керівні (адміністративні) посади на державній службі оцінюватимуться 3 точки зору володіння ними компетенцій лідерства. Зокрема, під час проведення конкурсу на посаду має оцінюватися, чи здатні кандидати слугувати прикладом етичної поведінки та дотримання принципів держслужби, бути спроможними досягати результатів, стратегічно мислити, управляти людськими ресурсами, демонструвати ефективну комунікацію в рамках виконання посадових обов’язків 
в майбутньому. Спеціальні інструменти оцінки можуть бути розроблені для визначення потенціалу лідера під час оцінювання кандидатів на керівні посади на державній службі в Україні» [2].

Висновки. Володіння лідерськими компетенціями будь-якої керівної посади ми бачимо в описі умов на посаду державного службовця. Можна знайти мільйони результатів в літературних джерелах та мережі Інтернет, що вкладається в цей термін і кожен 3 них містить різні варіації того, які саме якості належать до компетенції лідера. Тож, для кандидата на керівну посаду, остаточно варто визначитися: коли саме треба оцінити ці компетенції та про що саме в них йдеться. Згідно з дослідженнями, компетенції можуть бути розвинені на основі навчальних програм, коучинг-сесій i майстер-класів, оглядів результативності, а також шляхом навчання. Розвиток компетенцій та здібностей можна розділити на три етапи: допомогти людям отримати знання; розвинути розуміння, яким чином ці знання використовувати; дозволити зрозуміти, чому потрібно використовувати ці знання та компетенції. Таким чином, проаналізувавши сучасні підходи до лідерства ізнань, умінь, навичок, якими повинен володіти лідер, можна зробити головний висновок всіх сучасних теорій: справжній лідер - це командний гравець, тому на перше місце серед складових лідерської компетентності виходять здатності до колективної взаємодії.

\section{Стаття надійшла до редакції: 06.09.20}

Volodymyr Yemelyanov, Doctor of Sciences in Public Administration Institute of Public Administration, Black Sea National University of Petro Mohyla, Mykolaiv, Ukraine.

Oleksandr Shtyrov, $\mathrm{PhD}$ in Public Administration, Associate Professor, Institute of Public Administration, Petro Mohyla Black Sea National University, Mykolaiv, Ukraine.

Svitlana Verba, Senior Lecturer, Institute of Public Administration, Petro Mohyla Black Sea National University, Mykolaiv, Ukraine. 
Lybov Yaroshenko, Master of Public Administration Institute of Public Administration Black Sea National University of Petro Mohyla Mykolaiv, Ukraine.

\section{LEADERSHIP QUALITIES IN CIVIL SERVICE: PROBLEM ISSUES}

The article deals with management efficiency in the conditions of constant transformations in the country, when the role of the state is changed, public administration relations are changed, which require improvement of approaches to the formation of high-powered human resources with elements of leadership in public administration.

An analysis of the leadership qualities of civil servants and local government officials was made. Researches, which specified the list of leadership qualities of officials in public authorities, were conduct. It was found that leadership can be defined as one of the processes for management's organizing to achieve the best results in public activity.

It has been found that most leaders don't have innate leadership qualities. Therefore, it is necessary to develop these qualities through special training, if the leader understands his responsibility for his team, for the task and his responsibility before society.

There is a need to select among the civil servants to leadership positions people capable of leadership, or because of innate qualities, or acquired in the course of long-term work in government institutions. This is necessary for the development of professional service in Ukraine. But, unfortunately, this almost doesn't happen. Every year we lose competent professionals who are able to bring the country out of the economic, social and political crisis.

Key words: leadership, leader, professionalization, competence, selection of officials.

\section{Received: 06.09.20}




\section{References}

1. Liderstvo $v$ munitsypalnomu upravlinni: navchalno-metodychnyi posibnyk [Leadership in municipal management: a textbook]. (2013). Kyiv: DP «Ukrtekhinform» [in Ukrainian].

2. Profili kompetentsii liderstva na derzhavnii sluzhbi v Ukraini [Profiles of leadership competencies in the civil service in Ukraine]. www.center.gov.ua. Retrieved from http://www.center.gov.ua/attachments/article/14/\%D0\%9A\%D 0\%BE\%D0\%BC\%D0\%BF\%D0\%B5\%D1\%82\%D0\%B5\%D0\%BD\%D1\%86 $\% \mathrm{D} 1 \% 96 \% \mathrm{D} 1 \% 97$ \%D0\%BB\%D1\%96\%D0\%B4\%D0\%B5\%D1\%80\%D1\% $81 \% \mathrm{D} 1 \% 82 \% \mathrm{D} 0 \% \mathrm{~B} 2 \% \mathrm{D} 0 \% \mathrm{~B} 0 \% \mathrm{D} 0 \% \mathrm{~B} 2 \% \mathrm{D} 0 \% \mathrm{~A} 3 \% \mathrm{D} 0 \% \mathrm{BA} \% \mathrm{D} 1 \% 80 \%$ D0\%B0\%D1\%97\%D0\%BD $\%$ D1\%96.pdf

3. Stoliar, L. (2012). Problemy liderstva v derzhavnomu upravlinni [Problems of leadership in public administration]. Zbirnyk nauk. pr. Nats. akad. derzh. upr. pry Prezydentovi Ukrainy - Collection of scientific works of the National Academy of Public Administration under the President of Ukraine, 1, (pp. 58-65) [in Ukrainian].

4. Kholod, V.V. (2013). Derzhavne ta rehionalne upravlinnia: navch.-metod. rek. shchodo vyvchennia dysts. v umovakh ECTS (dlia stud. In-tu ekon. i upravlinnia napriamu pidhotovky 6.030601 «Menedzhment» den. ta zaoch. form navchannia) [State and regional management: teaching method. rivers regarding the study of dist. in the conditions of ECTS (for students of the Institute of Economics and Management in the direction of training 6.030601 «Management» of full-time and part-time forms of education)]. MOiN Ukrainy; Don. nats. un-t ekon. i torhivli im. M. Tuhan Baranovskoho. - Donetsk: DonNUET [in Ukrainian].

5. Kalashnikova, S.A. (2010). Osvitnia paradyhma profesionalizatsii upravlinnia na zasadakh liderstva [Educational paradigm of professionalization of management on the basis of leadership]. Kyiv: Kyiv universytet im. Borysa Hrinchenka [in Ukrainian].

6. Krychevskyi, R.L. (2007). Psykholohyia lyderstva : ucheb. posobye [Psychology of leadership: textbook. manual]. Moscow : Statut [in Russian].

7. Chernov, S.I. \& Haiduchenko, C.O. (2014). Vplyv liderstva na formuvannia ta rozvytok orhanizatsiinoi kultury v publichnomu upravlinni [Influence of leadership on the formation and development of organizational culture in public administration]. Efektyvnist derzhavnoho upravlinnia - Effectiveness of public administration, 40, (pp. 109-115) [in Ukrainian]. 
8. Vykhanskyi, O.S. \& Naumov, A.Y. (2001). Menedzhment : uchebnyk [Management: textbook]. Moscow : Hardaryky [in Russian].

9. Meskon, M. \& Albert, M. \& Khedouri, F. (1992). Osnovymenedzhmentu [Fundamentals of Management]. Moscow : Delo [in Russian].

10. Lohunova, M. (2006). Sotsialno-psykholohichni aspekty upravlinskoi diialnosti [Socio-psychological aspects of management]. Kyiv: Tsentr spryiannia instytutsionalnoho rozvytku derzhavnoi sluzhby [in Ukrainian].

11. Shatun, V.T. (2006). Osnovy menedzhmentu: Navchalnyi posibnyk [Fundamentals of Management: Textbook]. Mykolaiv: Vyd-vo MDHU im. Petra Mohyly [in Ukrainian].

12. Olshanskyi, D.V. (2004). Polityko-psykholohichna typolohiia liderstva [Political and psychological typology of leadership]. Moscow : Hardaryky [in Russian].

13. Merton, R. (1969). The social nature of leadership. Amer. journal of nature, 69, (pp. 78-95) [in English].

14. Ashyn, H.K. (1990). Lyderstvo: sotsyalno-polytycheskie y psykholohycheskie aspekty [Leadership: socio-political and psychological aspects]. Polytyka: problemy teoryy y praktyky - Politics: problems of theory and practice, VII, 2, (pp. 33-48) [in Russian].

15. Pyters, T. (2003). Lyderstvo - eshche ta zadachka [Leadership is another task]. Spravochnyk kadrovyka - Human Resources Handbook, 5, (pp. 98100) [in Russian].

16. Hainan, F. (1951). Group leadership and democratic action. Boston [in English].

17. Darmohrai, O. O. (2012). Vdoskonalennia styliu derzhavnoupravlinskoi diialnosti na osnovi vykorystannia osnovnykh pidkhodiv teorii liderstva [Improving the style of public administration on the basis of the use of basic approaches to leadership theories]. Derzhavne upravlinnia: udoskonalennia ta rozvytok - Public administration: improvement and development, 11. Retrieved from http://nbuv.gov.ua/UJRN/Duur_2012_11_8

18. Serheieva, L.M. \& Kondratieva, V.P. \& Khromei, M.Ia. (2015). Liderstvo: Navchalnyi posibnyk [Leadership: Textbook]. Ivano-Frankivsk., Lileia NV [in Ukrainian].

19. Loznytsia, V.S. (2007). Psykholohiia menedzhmentu: Navch. Posibnik [Psychology of management: Textbook Manual]. Kyiv: KNEU [in Ukrainian].

20. Krychevskyi, R.L. (2007). Psykholohyia lyderstva: uchebnoe posobye [Psychology of leadership: a textbook]. Moscow : Statut [in Russian]. 
21. Daft, R. (2014). Menedzhment [Management]. SPb. : Pyter [in Russian].

22. Platonov, Yu.P. (2007). Psykholohycheskye fenomeny povedenyia personala $v$ hruppakh y orhanyzatsyiakh: $v 2 t$. [Psychological phenomena of personnel behavior in groups and organizations: in 2 volumes]. SPb. : Rech, (Vols. 1) [in Russian].

23. Hoshovskoi, V.A. \& Pashko, L.A. \& Huka, A.K. (Eds.). (2015). Liderstvo $v$ mistsevomu samovriaduvanni : slovnyk terminiv [Liderstvo $v$ mistsevomu samovriaduvanni : slovnyk terminiv]. Kharkiv : Faktor [in Ukrainian].

24. Haiduchenko, S. (2012). Otsiniuvannia rivnia liderstva kerivnykiv nyzhchoi lanky u sferi publichnoi sluzhby [Estimation of the level of leadership of lower-level leaders in the field of public service]. Visnyk derzhavnoi sluzhby Ukrainy : nauk.-prakt. zhurn. - Bulletin of the State Service of Ukraine: scientific-practical magazine, 2, (pp. 26-29) [in Ukrainian].

25. Stogdill Ralph M. Handbook of Leadership: A Survey of Theory and Research. www.tandfonline.com. Retrieved from http://www.tandfonline.com/ doi/abs/10.1080/00220612.1975.10778712 [in English].

26. Orban-Lembryk, L.E. (2004). Sotsialna psykholohiia pidruch. dlia stud. vyshchykh navch. zakladiv: u $2 \mathrm{kn}$. [Social psychology textbook. for students. higher education institutions: in 2 books]. Kyiv: Lybid [in Ukrainian].

27. Romanchuk, I. \& Karnaukh, I. Osobystisna skladova profesiinoi kompetentnosti kerivnyka u sferi derzhavnoi sluzhby [Personal component of professional competence of the head in the field of civil service]. www.dridu. dp.ua. Retrieved from http://www.dridu.dp.ua/vidavnictvo/2010/2010_01(4)/1 Orivsds.pdf.

28. Honcharuk, N. (2007). Kerivnyi personal u sferi derzhavnoi sluzhby Ukrainy: formuvannia ta rozvytok: monohrafiia [Management staff in the field of civil service of Ukraine: formation and development: a monograph]. Dnipropetrovsk: DRIDU NADU [in Ukrainian].

29. Kovbasiuk, Yu. (2014). Rozvytok liderstva na derzhavnii sluzhbi yak umova nalezhnoho vriaduvannia [Leadership development in the civil service as a condition for good governance]. Daidzhest Natsionalnoi akademii derzhavnoho upravlinnia pry Prezydentovi Ukrainy - Digest of the National Academy of Public Administration under the President of Ukraine, 7 (13), (pp. 3-13) [in Ukrainian].

30. Pro zatverdzhennia Metodychnykh rekomendatsii z rozrobky profiliv profesiinoi kompetentnosti posad derzhavnoi sluzhby u derzhavnykh orhanakh, 
orhanakh vlady Avtonomnoi Respubliky Krym abo yikh aparati: Nakaz NADS No 148 vid 20.07.2012 r. [About the statement of Methodical recommendations on development of profiles of professional competence of positions of public service in state bodies, authorities of the Autonomous Republic of Crimea or their device: Order NADS No 148 from 20.07.2012]. nads.gov.ua. Retrieved from http://nads.gov.ua/control/uk/publish/article?art_id=598367\&cat_id=581194 [in Ukrainian].

31. Iukish, V.V. (2011). Suchasni naukovi pidkhody v zarubizhnii teorii menedzh-mentu do rozuminnia liderstva [Modern scientific approaches in foreign management theory to the understanding of leadership]. Stalyi rozvytok ekonomiky - Sustainable economic development, 6, (pp. 235-239).

32. Rabotaet ly vasha kompanyia ydealno? [Is your company working perfectly?]. powerbranding.ru. Retrieved from http://powerbranding.ru/biznesanaliz/mckinsey-7s-model/ [in Russian].

33. Telpis, O.V. (2011). Antropolohichna pryroda politychnoho liderstva v mizhnarodnykh vidnosynakh [Anthropological nature of political leadership in international relations]. Aktualni problemy mizhnarodnykh vidnosyn - Actual problems of international relations, 103(1), (pp. 236-247) [in Ukrainian].

34. Veselska, A.L. (2014). Hendernyi aspekt liderstva: teoretychnyi analiz [Gender aspect of leadership: a theoretical analysis]. Nauka i osvita - Science and Education , 5 (122), (pp. 19-24) [in Ukrainian].

35. Volkivska, D.A. (2014). Suchasni pidkhody do vyznachennia liderstva [Modern approaches to the definition of leadership]. Visnyk Chernihivskoho natsionalnoho pe $\neg$ dahohichnoho universytetu. Ser: Pedahohichni nauky Bulletin of the Chernihiv National Pedagogical University. Ser.: Pedagogical sciences, 115, (pp. 45-47) [in Ukrainian].

36. Adamovska, V.S. \& Romanenko, Yu.I. (2019). Teoretychni zasady ta metodychni pidkhody do otsinky liderskykh yakostei derzhavnoho sluzhbovtsia [Theoretical principles and methodological approaches to assessing the leadership qualities of civil servants]. Derzhavne upravlinnia: udoskonalennia ta rozvytok-Public administration: improvement and development, 5. Retrieved from http://www.dy.nayka.com.ua/?op=1\&z=1438. DOI: 10.32702/2307-21562019.5.27 [in Ukrainian]. 


\section{Відомості про авторів / Information about the Authors}

Смельянов Володимир Михайлович: Чорноморський національний університет ім. Петра Могили: вул. 68 десантників 10, Миколаїв, 54003, Україна.

Volodymyr Yemelyanov: Petro Mohyla Black Sea National University: 68 Desantnykiv str. 10, Mykolaiv, 54003, Ukraine.

\section{ORCID.ORG/0000-0002-2995-8445}

\section{E-mail: d_idu@ukr.net}

Штирьов Олександр Миколайович: Чорноморський національний університет ім. Петра Могили: вул. 68 десантників 10, Миколаїв, 54003, Україна.

Oleksandr Shtyrov: Petro Mohyla Black Sea National University: 68 Desantnykiv str. 10, Mykolaiv, 54003, Ukraine.

ORCID. ORG./ 0000-0002-7627-3721

\section{E-mail: bratislava@ukr.net}

Верба Світлана Миколаївна: Чорноморський національний університет ім. Петра Могили: вул. 68 десантників 10, Миколаїв, 54003, Україна.

Svitlana Verba: Petro Mohyla Black Sea National University: 68 Desantnykiv str. 10, Mykolaiv, 54003, Ukraine.

ORCID. ORG./ 0000-0002-6156-1384

E-mail: mag_idu@ukr.net 
Ярошенко Любов Сергіївна: Чорноморський національний університет ім. Петра Могили: вул. 68 десантників 10, Миколаїв, 54003, Україна.

Lybov Yaroshenko: Petro Mohyla Black Sea National University: 68 Desantnykiv str. 10, Mykolaiv, 54003, Ukraine.

E-mail: luba.yaroshenko12@gmail.com 